\title{
Optimalisasi Penggunaan Ms Excel Terhadap Kepekaan Data Informasi Kesehatan di Posyandu
}

\author{
Evina Widianawati ${ }^{1}$, Faik Agiwahyuanto ${ }^{2}$, Widya Ratna Wulan ${ }^{3}$ \\ ${ }^{1,2,3}$ Prodi D3 Rekam Medis Dan Informasi Kesehatan, \\ Universitas Dian Nuswantoro Semarang \\ Email: ${ }^{1}$ evina.widianawati@dsn.dinus.ac.id \\ Email: ${ }^{2}$ faik.agiwahyuanto@dsn.dinus.ac.id, ${ }^{3}$ widya.ratna.wulan@dsn.dinus.ac.id
}

\begin{abstract}
Children growth needs to be monitored to prevent undernourised, stunting and various other growth disorder. Ms Excel can be used as a monitoring tool for childrens growth so the recording, storage and processing of health information data will be easier, more accurate and analytical. This study aims to obtain information on the use of Ms Excel and its influence on the sensitivity of health information. The research design used is descriptive research with quantitative approach. The population is Posyandu representative and community representative in Kedungori village Dempet Demak as many as 36 people. Variable of this study is : Constraints on the Use of Ms Excel (X), Implementation on the Use of Ms Excel (Y) and Sensitivity of Health Information (Z). Data were analyzed using descriptive analysis for variable $X$ and linier regression analysis for variable $Y$ and $Z$. The result show that the Posyandu representative still didn't use Ms Excel because they couldn't use Excel and the implementation of using Ms Excel affected the sensitivity of health information data.
\end{abstract}

Keywords: health, Ms Excel, Posyandu, sensitivity, utilization

\begin{abstract}
Abstrak
Tumbuh kembang balita perlu dimonitoring untuk mencegah balita gizi kurang, stunting dan berbagai gangguan pertumbuhan balita yang lainnya. Ms Excel dapat dijadikan sebagai alat monitoring tumbuh kembang balita oleh kader Posyandu sehingga pencatatan, penyimpanan dan pengolahan data informasi kesehatan akan lebih mudah, akurat $\&$ analitis. Penelitian ini bertujuan untuk memperoleh informasi penggunaan Ms Excel dan pengaruhnya terhadap kepekaan informasi kesehatan pada kader Posyandu. Desain penelitian yang digunakan adalah penelitian deskriptif dengan pendekatan kuantitaif. Populasi yaitu kader posyandu dan wakil masyarakat di Desa Kedungori kecamatan Dempet Demak sebanyak 36 orang. Variabel penelitian antara lain : Kendala Penggunaan Ms Excel (X), Implementasi Penggunaan Ms Excel (Y), Kepekaan Informasi Kesehatan (Z). Data dianalisis menggunakan analisis deskriptif untuk variabel $\mathrm{X}$, dan analisis regresi linier untuk variabel Y dan Z. Hasil penelitian menunjukkan kader Posyandu masih belum menggunakan Ms Excel dikarenakan tidak bisa menggunakan Excel dan implementasi penggunaan Ms Excel berpengaruh terhadap kepekaan data informasi kesehatan.
\end{abstract}

Kata kunci: kepekaan, kesehatan, Ms Excel, penggunaan, Posyandu

\section{PENDAHULUAN}

Tumbuh kembang balita perlu dimonitoring untuk mencegah balita gizi kurang, stunting dan berbagai gangguan pertumbuhan balita yang lainnya. Dalam memantau tumbuh kembang anak, pemerintah melalui program Posyandu melakukan pengukuran tinggi badan, menimbang berat badan balita serta pemberian vitamin yang rutin dilakukan setiap bulan.

Posyandu sangat berperan aktif dalam memantau tumbuh kembang balita, khususnya dalam pemeriksaan, pencatatan dan pelaporan data kesehatan balita kepada Puskesmas. Kader sebagai penggerak Posyandu, menjadi kunci keberhasilan Posyandu (Susilowati, 2012). Kader Posyandu perlu dibina dan diarahkan oleh Puskesmas sebagai penanggung jawab utama kesehatan masyarakat dilingkungannya. Kader diharapkan dapat menjembatani antara petugas/ahli kesehatan dengan masyarakat serta membantu masyarakat mengidentifikasi dan menghadapi dan menjawab kebutuhan kesehatan (Iswarawanti, 2010). 
Kader Posyandu dibekali petugas kesehatan informasi-informasi kesehatan yang bermanfaat bagi warga sekitar. Tugas kader Posyandu selain memberikan informasi kesehatan bagi warga, juga melakukan pemeriksaan, pencatatan dan pelaporan data kesehatan balita. Untuk meningkatkan kesehatan tumbuh kembang balita, diharapkan kader Posyandu lebih peka terhadap hasil laporan data kesehatan yang diperoleh dari hasil pemeriksaan berat badan dan tinggi badan balita. Dengan adanya kader posyandu yang peka data kesehatan serta komunikatif dengan ibu balita maka diharapkan kesehatan tumbuh kembang balita meningkat.

Pencatatan .dan .pelaporan .adalah salah satu dari tiga .komponen .utama untuk.melakukan monitoring dan evaluasi (Kemenkes, 2014). Pencatatan data kesehatan anggota Posyandu selama ini dilakukan secara manual. Setiap balita memiliki satu kartu data kesehatan yang berisi berat badan dan tinggi badan setiap bulannya. Kader Posyandu dalam melakukan analisa terhadap data pasien perlu membuka satu per satu kartu, mengecek satu per satu berat badan dan tinggi badan balita, kemudian mencatat di buku besar.

Pendataan dengan buku catatan manual mengalami banyak kendala seperti lama dan salah dalam pendataan, pengolahan, dan pelaporan. Kendala lain adalah buku catatan sering rusak, hilang, ganti buku, sulit dibaca, sehingga sulit mendeteksi perkembangan balita (Supriyanto, 2017). Hal ini tentu akan memperlambat kegiatan analisis, sehingga upaya preventif/ pencegahan penyakit tidak optimal.

Dalam rangka mengatasi kendala tersebut serta meningkatkan kepekaan kader Posyandu terhadap data rekam medis anggota Posyandu, diperlukan alat pencatatan yang lebih cepat, mudah, akurat dan analitis. Ms Excel adalah salah satu alat analitis yang mudah dan cukup terkenal. Hampir setiap komputer memiliki program Ms Excel, sehingga aksesnya mudah didapat. Selain itu, penggunaan Ms Excel juga tidak sulit, bahkan bisa digolongkan mudah apabila dijalankan sesuai petunjuk. Ms Excel diperlukan oleh kader Posyandu guna membantu kader dalam melakukan kegiatan pencatatan dan administrasi data yang lebih baik (Wanti \& Tripustikasari, 2019).

Untuk mewujudkan Sistem Informasi Kesehatan (SIK) dengan dukungan teknologi dalam rangka mempermudah pelaporan khususnya data kesehatan di Posyandu, dimana data kesehatan Posyandu direkap secara manual dengan menulis di buku. Untuk itu dilakukan pendataan berbasis Ms. Excel guna mendapatkan rekap data dan laporan yang lebih mudah, akurat \& analitis. Ms. Excel mempermudah dalam pengolahan data, analisis maupun pelaporan hasil kegiatan oleh kader Posyandu ke Puskesmas (Deharja,2019)

Terdapat berbagai kendala dalam menggunakan Ms Excel yang bisa dibedakan menjadi 2 aspek yaitu kendala teknis dan kendala persepsi. Kendala teknis berupa pengetahuan pengolahan data dengan menggunakan Excel sedangkan kendala persepsi berupa sikap atau persepsi kader terhadap penggunaan Excel. Sikap / persepsi terhadap penggunaan (attitude toward using) mempengaruhi niat perilaku terhadap penggunaan teknologi (behavior intention of use) (Ardhiani, 2019).

Kader diharapkan dapat memberikan pelaporan yang baik secara berkelanjutan terhadap temuan kasus yang ada di masyarakat kepada pihak puskesmas. Sehingga temuan kasus tersebut dapat segera mendapatkan penanganan dan diharapkan tercapainya peningkatan status kesehatan anak. Karena dengan status kesehatan yang baik anak dapat berkembang secara optimal (Adistie, 2017). Dengan menggunakan Ms Excel diharapkan kader Posyandu menjadi lebih peka terhadap data sehingga tindakan pencegahan penyakit lebih optimal.

Berdasarkan penelitian 2019 di Kecamatan Dempet Kabupaten Demak, diketahui bahwa 40 dari 229 balita atau sebesar $17,4 \%$ balita mengalami stunting ( kekurangan tinggi badan dibandingkan umur). Puskesmas dengan cepat melakukan tindakan perbaikan agar stunting dapat berkurang. Kader Posyandu berperan aktif dalam memonitoring stunting di Dempet. Selain berperan dalam monitoring stunting, kader posyandu juga diharapkan dapat melakukan pencegahan penyakit di kecamatan Dempet dengan memantau data rekam medis anggota Posyandu menggunakan Ms Excel. Dengan menggunakan Ms Excel diharapkan kader Posyandu lebih peka terhadap data informasi kesehatan anggota Posyandu sehingga stunting di Dempet berkurang serta tumbuh kembang anak terpantau dengan baik.

Penelitian ini bertujuan untuk memperoleh informasi penggunaan dan kendala Ms Excel serta pengaruh implementasi penggunaan Ms Excel terhadap kepekaan informasi kesehatan pada kader Posyandu.

\section{METODE}

Desain penelitian yang digunakan yaitu penelitian deskriptif dengan pendekatan kuantitatif yaitu 
analisis kuantitatif secara deskriptif, dan analisis kuantitatif secara inferensial. Variabel penelitian antara lain : Kendala Penggunaan Ms Excel (X), Implementasi Penggunaan Ms Excel (Y), Kepekaan Informasi Kesehatan dari laporan $\operatorname{Excel(Z).~}$

Populasi yaitu kader posyandu dan petugas puskesmas serta wakil masyarakat di Desa Kedungori kecamatan Dempet Demak sebanyak 36 orang. Sample yang digunakan adalah seluruh anggota populasi.

Instrument penelitian yang digunakan adalah Angket Implemetasi Penggunaan dan Kepekaan Informasi Kesehatan menggunakan Ms Excel. Data diambil pada bulan oktober 2019. Data dianalisis menggunakan analisis deskriptif untuk variabel $X$, dan analisis regresi linier untuk variabel $\mathrm{Y}$ dan $\mathrm{Z}$.

\section{HASIL}

Hasil Analisis Deskriptif Profil Responden

Tabel 1 Profil Responden

\begin{tabular}{|c|l|l|l|}
\hline No & Umur & Frekuensi & $\begin{array}{c}\text { Frekuensi } \\
\text { Relatif }\end{array}$ \\
\hline 1 & $<=25$ th & 0 & $0 \%$ \\
\hline 2 & $26-35$ th & 10 & $28 \%$ \\
\hline 3 & $36-45$ th & 8 & $22 \%$ \\
\hline 4 & $46-55$ th & 12 & $33 \%$ \\
\hline 5 & $>55$ th & 6 & $17 \%$ \\
\hline \multicolumn{2}{r|}{ Total } & 30 & $100 \%$ \\
\hline
\end{tabular}

Dari total 36 responden, $50 \%$ responden berusia 4655th dan $>$ 55th, artinya sebagian kader Posyandu sudah berusia cukup tua, sedangkan sebagian sisanya masih berusia muda.

\section{Hasil Analisis Deskriptif Skor Angket}

Berikut hasil analisa deskriptif rata-rata skor angket yang disajikan pada Gambar 1. Rata-rata skor angket.

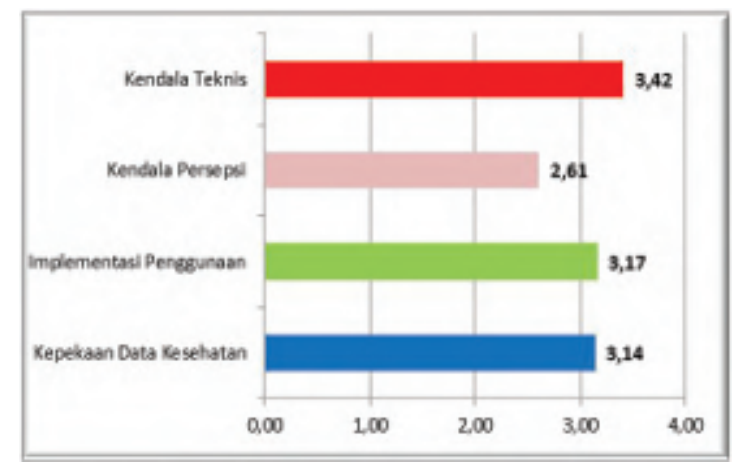

Gambar 1. Rata-rata skor angket
Pada variabel kendala penggunaan dibedakan menjadi 2 yaitu kendala teknis dan kendala persepsi. Dari rata-rata skor angket terlihat bahwa skor kendala teknis 3,42 lebih tinggi dari skor kendala persepsi yaitu 2,61. Hal ini berarti responden mengalami lebih banyak kendala teknik dalam penggunaan Ms Excel, sedangkan secara presepsi responden tidak merasa terkendala. Untuk lebih detail, akan dijabarkan analisis setiap item pertanyaan pada aspek kendala penggunaaan. Berikut hasil rata-rata skor item pertanyaan pada aspek kendala teknis dan kendala persepsi yang disajikan pada Tabel 2 .

Tabel 2. Analisis item pertanyaan aspek kendala penggunaan

\begin{tabular}{|c|c|c|}
\hline Aspek & Item Pertayaan & $\begin{array}{l}\text { AVG } \\
\text { Skor }\end{array}$ \\
\hline \multirow{4}{*}{$\begin{array}{l}\text { Ke n d a l a } \\
\text { Teknis }\end{array}$} & $\begin{array}{l}\text { Saya tidak punya } \\
\text { komputer }\end{array}$ & 3,39 \\
\hline & $\begin{array}{l}\text { Saya tidak tahu Ms } \\
\text { Excel }\end{array}$ & 3,44 \\
\hline & $\begin{array}{l}\text { Saya tidak pernah } \\
\text { mengikuti pelatihan } \\
\text { Ms Excel }\end{array}$ & 3,39 \\
\hline & $\begin{array}{l}\text { Saya tidak bisa } \\
\text { mengoperasikan Ms. } \\
\text { Excel }\end{array}$ & 3,44 \\
\hline \multicolumn{2}{|c|}{ Rata-rata Kendala Teknis } & 3,42 \\
\hline \multirow{4}{*}{$\begin{array}{l}\text { K e n d a l a } \\
\text { Persepsi }\end{array}$} & $\begin{array}{l}\text { Umur sudah tidak } \\
\text { muda }\end{array}$ & 2,78 \\
\hline & Merepotkan & 2,56 \\
\hline & Saya sibuk bekerja & 2,72 \\
\hline & $\begin{array}{l}\mathrm{S} \text { a y a m a } 1 \text { a } \mathrm{s} \\
\text { mempelajari hal-hal } \\
\text { baru. }\end{array}$ & 2,39 \\
\hline \multicolumn{2}{|c|}{ Rata-rata Kendala Persepsi } & 2,61 \\
\hline
\end{tabular}

Dari tabel 2. Terlihat bahwa pada kendala teknis, responden tidak tahu dan tidak bisa mengoperasikan Ms Excel adalah kendala terbesar (skor 3,44), sedangkan pada aspek kendala persepsi responden merasa umur yang tidak muda lagi menjadi kendala terbesar dalam menggunakan Excel (skor 2,78)..

Pada variabel implementasi penggunaan Excel diperoleh gambar 1. skor rata-rata angket adalah 3,17 yang artinya responden cukup mampu mengoperasikan Excel. Berikut detail analisis item pertanyaan pada aspek implementasi penggunaan. 
Tabel 3. Analisis item pertanyaan aspek implementasi penggunaan Excel

\begin{tabular}{|l|l|}
\hline \multicolumn{1}{|c|}{$\begin{array}{c}\text { Item Pertayaan Implemetasi } \\
\text { Penggunaan Excel }\end{array}$} & \multicolumn{1}{c|}{$\begin{array}{c}\text { AVG } \\
\text { Skor }\end{array}$} \\
\hline $\begin{array}{l}\text { Mampu input, edit \& simpan di Ms. } \\
\text { Excel }\end{array}$ & 3,11 \\
\hline Mengetahui menu utama di Ms. Excel & 3,17 \\
\hline Mampu mengolah data di Ms. Excel & 3,33 \\
\hline $\begin{array}{l}\text { Mampu membuat \& memahami grafik } \\
\text { di Excel }\end{array}$ & 2,94 \\
\hline $\begin{array}{l}\text { Mampu menarik kesimpulan dr laporan } \\
\text { Ms. Excel }\end{array}$ & 3,28 \\
\hline $\begin{array}{l}\text { Rata-rata Implementasi Penggunaan } \\
\text { Excel }\end{array}$ & 3,17 \\
\hline
\end{tabular}

Dari Tabel 3. diketahui responden cukup mampu mengoperasikan Excel dengan mengetahui menu utama, input data, olah data, simpan serta menarik kesimpulan. Namun responden masih sedikit kesulitan dalam membuat dan memahami grafik di Excel. Hal ini berarti kader Posyandu cukup mampu menggunakan Ms Excel sehingga diharapkan pencatatan dan pelaporan data kesehatan menjadi lebih mudah dan sistematis.

Pada variabel kepekaan informasi kesehatan diperoleh gambar 1. skor rata-rata angket adalah 3,14 yang artinya responden cukup peka terhadap informasi kesehatan yang dihasilkan dari laporan Excel. Berikut detail analisis item pertanyaan pada aspek kepekaan informasi kesehatan.

Tabel 4. Analisis item pertanyaan aspek kepekaan data kesehatan

\begin{tabular}{|l|l|}
\hline \multicolumn{1}{|c|}{$\begin{array}{c}\text { Item Pertayaan Kepekaan Data } \\
\text { Kesehatan }\end{array}$} & $\begin{array}{c}\text { AVG } \\
\text { Skor }\end{array}$ \\
\hline $\begin{array}{l}\text { Mampu menganalisis data rekam medis } \\
\text { anggota Posyandu (sehat/tidak sehat) } \\
\text { dari laporan Excel }\end{array}$ & 3,17 \\
\hline $\begin{array}{l}\text { Mengetahui kejanggalan data rekam } \\
\text { medis anggota Posyandu dari laporan } \\
\text { Excel }\end{array}$ & 3,33 \\
\hline $\begin{array}{l}\text { ampu mencari sumber masalah dari data } \\
\text { janggal dari laporan Excel }\end{array}$ & 2,94 \\
\hline $\begin{array}{l}\text { Mampu mengusulkan tindakan } \\
\text { pencegahan penyakit pada anggota } \\
\text { Posyandu dari laporan Excel }\end{array}$ & 3,00 \\
\hline $\begin{array}{l}\text { Menjadi lebih peka terhadap informasi } \\
\text { kesehatan anggota Posyandu dari } \\
\text { laporan Excel }\end{array}$ & 3,28 \\
\hline
\end{tabular}

\begin{tabular}{|c|c|}
\hline $\begin{array}{c}\text { Item Pertayaan Kepekaan Data } \\
\text { Kesehatan }\end{array}$ & $\begin{array}{c}\text { AVG } \\
\text { Skor }\end{array}$ \\
\hline Rata-rata Kepekaan Data Kesehatan & 3,14 \\
\hline
\end{tabular}

Dari Tabel 4. diketahui responden cukup peka terhadap informasi kesehatan yang dihasilkan dari laporan Excel dengan menganalisis data rekam medis anggota posyandu, mengetahui kejanggalan data, mengusulkan tidakan pencegahan penyakit dan lebih peka terhadap informasi kesehatan dari laporan Excel. Namun responden masih sedikit kesulitan dalam mencari sumber masalah dari data yang janggal. Hal ini berarti kader Posyandu peka dan dapat memahami hasil laporan Ms Excel sehingga diharapkan akan memberikan dampak positif bagi optimalisasi kesehatan anggota Posyandu.

\section{Hasil Analisis Regresi Linier}

\section{uji persyaratan}

Hasil uji nornalitas menunjukkan bahwa data berdistribusi normal, dimana; nilai $\mathrm{p}=0.068(>0.05)$ dan $\mathrm{p}=0,278(>0.05)$. Dan tidak terjadi autokorelasi; $\mathrm{dU}=1,4107<$ Nilai durbin watson $=1,663<4-\mathrm{dU}$ $=2,5893$.

\section{Tabel 5 Uji regresi linier}

\begin{tabular}{|l|c|c|c|c|}
\hline Constan & B & SE & Beta & Sig(P) \\
\hline 10.528 & 0.328 & 2.531 & 0.324 & 0.039 \\
\hline
\end{tabular}

Tabel 5 menunjukkan bahwa nilai $\mathrm{p}=0.039(\mathrm{p}<0.05)$, artinya ada pengaruh implementasi penggunaan Excel terhadap kepekaan data kesehatan.

Rumus regresi linier yaitu $\mathrm{Y}=\mathrm{a}+\mathrm{bx}$, dimana $\mathrm{x}$ adalah variabel implementasi penggunaan Excel, $\mathrm{Y}$ adalah kepekaan data kesehatan, $\mathrm{a}=$ koefisien constant, $\mathrm{b}=$ koefisien implementasi. Rumus persamaan regesi liner adalah $Y=10528+0,328 X$. Nilai $R$ square adalah $12 \%$ artinya implementasi penggunaan Ms Excel mempengaruhi kepekaan data kesehatan sebesar $12 \%$, sisanya dipengaruhi oleh variabel lain.

\section{PEMBAHASAN}

Dari hasil penelitian diketahui bahwa 50\% responden berusia 46-55th dan $>55$ th, artinya sebagian kader Posyandu sudah berusia cukup tua. Jika dari hasil kuesioner kendala persepsi, umur yang tidak muda lagi menjadi kendala responden dalam menggunakan Excel. Sedangkan pada kuesioner kendala teknis, 
kendala terbesar karena responden tidak bisa menggunakan Excel.

Pada aspek kendala persepsi responden merasa umur yang tidak muda lagi menjadi kendala terbesar dalam menggunakan Excel (skor 2,78). Umur mempunyai kaitan erat dengan tingkat kedewasaan seseorang yang berarti kedewasaan teknis dalam arti keterampilan melaksanakan tugas maupun kedewasaan psikologis.(Lubis \& Syahri, 2015). Namun tidak sejalan dengan hasil penelitian Simanjuntak (2012) yang menyatakan bahwa tidak terdapat hubungan umur dan pekerjaan dengan kinerja kader posyandu.

Pada aspek implementasi penggunaan mendapat skor rata-rata 3,17 dari 5 artinya reponden cukup mampu menggunakan Excel, namun masih terkendala dalam membuat dan memahami grafik Excel. Hal ini berarti kader Posyandu cukup mampu menggunakan Ms Excel sehingga diharapkan pencatatan dan pelaporan data kesehatan menjadi lebih mudah dan sistematis.

Pada aspek kepekaan data kesehatan mendapat skor rata-rata 3,14 dari 5 artinya responden cukup peka terhadap data kesehatan dari hasil laporan excel, namun masih terkendala dalam mencari sumber asal kejanggalan data. Hal ini berarti kader Posyandu peka dan dapat memahami hasil laporan Ms Excel sehingga diharapkan akan memberikan dampak positif bagi optimalisasi kesehatan anggota Posyandu.

Pada hasil uji regresi linier, diketahui bahwa implementasi penggunaan Excel mempengaruhi kepekaan data kesehatan sebesar $12 \%$, sisanya dipengaruhi oleh variabel lain. Excel dapat memberikan manfaat yang cukup banyak yaitu selain sebagai alat penyimpanan, pengolahan data, Excel juga membantu kader Posyandu untuk lebih peka terhadap data kesehatan anggota Posyandu.

\section{SIMPULAN}

Pada aspek kendala, umur yang tidak muda lagi menjadi kendala responden dalam menggunakan Excel. Pada aspek implementasi penggunaan Excel diketahui kader Posyandu cukup mampu menggunakan Ms Excel. Pada aspek kepekaan data, kader Posyandu peka dan dapat memahami hasil laporan Ms Excel sehingga diharapkan akan memberikan dampak positif bagi optimalisasi kesehatan anggota Posyandu. Penggunaan Excel dapat memberikan manfaat yang cukup banyak yaitu selain sebagai alat penyimpanan, pengolahan data, Excel juga membantu kader Posyandu untuk lebih peka terhadap data kesehatan anggota Posyandu sehingga diharapkan kader mampu melakukan tindakan pencegahan penyakit pada anggota Posyandu.

\section{UCAPAN TERIMA KASIH}

Ucapan terima kasih ditujukan kepada Fakultas Kesehatan Universitas Dian Nuswantoro Semarang atas ijin penelitian dan pengabdiannya.

\section{DAFTAR PUSTAKA}

Adistie, dkk. Pengetahuan Kader Kesehatan Tentang Deteksi Dini Gizi Buruk Pada Balita (Studi Kasus Di Wilayah Kerja Puskesmas Kecamatan Parigi Kabupaten Pangandaran). Dharmakarya: Jurnal Aplikasi Ipteks untuk Masyarakat, Vol. 6, No. 3, September 2017: $173-177$, ISSN $1410-5675$.

Ardhiani, Lisa Noor. Analisis Faktor-Faktor Penerimaan Penggunaan Quipperschool. com Dengan Menggunakan Pendekaatan Technology Acceptance Model (TAM) Dan Theory OF Planned Behavior (TPB) Di SMA N 7 YOGYAKARTA. 2015 [diakses tanggal 20 Januari 2019]; Available From: Http:// Eprints.Uny.Ac.Id/20550/

Deharja, dkk. 2019.Peningkatan Kompetensi Kader Dalam Pembuatan Laporan Posyandu Berbasis Teknologi Informasi. Seminar Nasional Hasil Pengabdian Masyarakat dan Penelitian Pranata Laboratorium Pendidikan Politeknik Negeri Jember Tahun 2019, ISBN : 978-602-14917-8-2.

Iswarawanti, D. N. 2010. Kader Posyandu: Peranan Dan Tantangan Pemberdayaannya Dalam Usaha Peningkatan Gizi Anak Di Indonesia. Jurnal Manajemen Pelayanan Kesehatan, Vol. 13, No. 4 Desember 2010

Kementerian Kesehatan Republik Indonesia Direktorat Jenderal Pengendalian Penyakit Dan Penyehatan Lingkungan. Pedoman Nasional Pengendalian Tuberkulosis; 2014 [cited 14 Januari 2019]; Available from: www.tbindonesia.or.id/opendir/Buku/bpn_ptb_2014.pdf 
Lubis \& Syahri. 2015. Pengetahuan Dan Tindakan Kader Posyandu Dalam Pemantauan Pertumbuhan Anak Balita. Jurnal Kesehatan Masyarakat, KEMAS 11 (1) (2015) 65-73, ISSN 1858-1196.

Simanjuntak, M. 2012. Karakteristik Sosial Demografi Dan Faktor Pendorong Peningkatan Kinerja Kader Posyandu. Jurnal Wira Ekonomi Mikroskil, Volume 2, Nomor 01, April 2012.

Supriyanto, dkk. 2017. Peran Teknologi Informasi Bagi Kader Posyandu Dalam Kegiatan Pendataan K.I.A. Seminar Nasional Vokasi dan Teknologi (SEMNASVOKTEK). ISSN Cetak : 2541-2361 | ISSN Online : 2541-3058.

Susilowati, U. 2012. Pengaruh Pendidikan Kesehatan Terhadap Pengetahuan Kader Tentang Tugas Kader Posyandu. Jurnal Kebidanan, Vol. IV, No. 02, Desember 2012.

Wanti \& Tripustikasari. 2019. Pelatihan Komputer Dasar Bagi Kader Pkk Dan Posyandu Di Desa Patikraja. Madani : Indonesian Journal Of Civil Society Vol. 1, No.1, Agustus 2019, pp. 17-23. 